\title{
Profitability Analysis of Value Added Usipa \\ (Engraulicypris Sardella) by Packaging in Nkhotakota, \\ Malawi
}

\begin{abstract}
Mbamba $\mathrm{D}^{1 *}$, Valeta $\mathrm{J}^{2}$, Harawa $\mathrm{D}^{3}$, Kapute $\mathrm{F}^{1}$, Singini $\mathrm{W}^{1}$ and Mzengereza $\mathbf{K}^{1}$

${ }^{1}$ Department of Fisheries and Aquatic Science, Mzuzu University, Luwinga, Malawi

${ }^{2}$ Department of Aquaculture and Fisheries Science, Lilongwe University of Agriculture and Natural Resources, Lilongwe, Malawi

${ }^{3}$ Department of Tourism and Hospitality management, Mzuzu University, Luwinga, Malawi
\end{abstract}

Research article

Volume 2 Issue 3

Received Date: May 15, 2018

Published Date: May 31, 2018

DOI: $10.23880 /$ jenr-16000134

*Corresponding author: Mbamba D, Department of Fisheries and Aquatic Science, Mzuzu University, Luwinga, Mzuzu 2, Malawi, Email: Dgmbamba32@gmail.com

\section{Abstract}

The study was conducted to determine the profitability of value addition of Usipa (Engraulicypris sardella) through packaging in Nkhotakota district, central Malawi. Samples $(69 \mathrm{Kg}$ ) of fresh E. sardella purchased and sundried in solar tent dryer, packaged $(34.5 \mathrm{Kg})$ in plastics papers while the other $34.5 \mathrm{Kg}$ was unpackaged. Sales data were analyzed using gross margin and net profit analysis. Benefit-cost ratio and rate of return on investment were used to determine the viability of small scale E. sardella fish business. Results of Cost and Return Analysis of packaged E. sardella showed that the total revenue of packaged E. sardella was Mk225,400.00 and total cost was Mk 40,350.00 while results for unpackaged $E$. sardella showed that the total revenue was Mk104,144.92 and total cost was Mk20,450.00. Results on Benefit cost ratio for packaged and unpackaged E. sardella were 5.09 and 5.58 respectively. The findings imply that packaged E. sardella was more profitable than unpackaged E. sardella. The rate of return for packaged and unpackaged Engraulicypris sardella was 4.58 and 4.09 respectively, implying that for every Mk1.00 invested for Packaged Engraulicypris sardella there was a return of Mk4.58 and Mk4.09 for unpackaged Engraulicypris sardella. Packaging should be encouraged to maximize profits from small scale fish business in Malawi.

Keywords: Profitability; Packaged and unpackaged Engraulicypris sardella; Fisheries 


\section{Journal of Ecology \& Natural Resources}

\section{Introduction}

Fish is a valuable and nutritious food substance, and an essential source of high quality and cheap animal protein crucial to the balance of diets in marginally food secure communities [1]. Nearly half a billion people globally rely on fish and fisheries products for income and fish provide about $15 \%$ of the animal protein in the diets of three billion people [2].

Fish and the fisheries sector are of significant social and economic importance to Malawi. Fish provides over $70 \%$ of the dietary animal protein intake for Malawians and $40 \%$ of the total protein supply [1]. In Malawi, much of the fish is consumed in rural areas thereby contributing directly and significantly to daily nutritional requirements [3]. The Fisheries sector in Malawi is a chief livelihood mainstay to approximately 60,000 fishers and about 500,000 people are involved in fish processing, fish marketing and other fisheries related activities [4]. Fish acts as a source of income for the people of Malawi, generating beach price local revenue of about MK2.6 billion (US $\$ 24$ million) annually, and contributes about $4 \%$ to the GDP $[5,6]$. In recent years, fish landings have predominantly comprised of small cichlids, Engraulicypris sardella (Usipa) and Copadichromis spp (Utaka) replacing the species deemed to be of high economic value that have for the past two decades declined remarkably [7]. The production of small species (Usipa - (E. Sardella), Kambuzi (Nyassachromis spp) and Utaka (Copadichromis spp.) has doubled from 56,463 tons in 2004 to 98, 299 tons in 2010 while production of bigger species continues to dwindle [8]. However, peak catch for small fish species is between January and April, a period associated with heavy rains and high humidity which results in high postharvest losses. In fisheries, post-harvest losses have been defined as a reduction in quantity, or quality as well as monetary value of fish in the supply chain. The numerous negative repercussions of post-harvest losses have impacted the livelihoods of the fisher folks in Malawi among them in Linga fishing community in Nkhotakota district [9]. The decline and change in catches composition has negatively affected fish processing and marketing activities. The low supply of high valued fish and limited skills in handling the small species that has dominated the catches from the lake has caused a stiff competition amongst the fisher folks of Linga EPA causing some members of the society to fall out of fish business [9]. Evidence exist that majority of fisher folks lacked technical and financial capacity to conduct value addition like packaging to make them more attractive to the consumers and prevent post harvest losses. In addition, fisher folks are also not aware of the profitability of packaging their products because such information is scanty. Thus, they experience massive catch deterioration and low sales. As a result, this has reduced income among the fisheries-dependent households making them more vulnerable and less resilient to impacts of climate change especially women who actively participate in fish processing. Loss of income coupled with few alternative livelihood opportunities has degenerated into massive poverty, increased malnutrition and food insecurity in Linga EPA.

One of the panacea to curb post-harvest losses of highly perishable products like fish by changing it into a form that increase its shelf life. Mostly, methods that increase shelf life also improves the value of the products which fetches highly on the market thereby enhancing the profitability of products. Russel, et al., asserts that one of the reasons for promoting value added production is to achieve higher profits. Producers that are involved with value addition are in a position to fetch a larger share of the food dollar by producing what consumers demand instead of producing or delivering only raw material [10]. Fish and fishery value-added products have been traded on the global market place between the major fishing nations for decades [11]. The challenge, however, has been that, most of the developing country fish suppliers act as raw material suppliers to the industrial nations, from which they earn little profit from valuable natural resources [12].

Good packaging materials improve the handling and shelf life of the products [12]. Consumers are interested to know whether the product being purchased is right for them and the package is the only source of information available Susan, 1988 [13]. For food products, consumers are interested in nutritional information since they are health and diet conscious and packaged food provide that information. In addition, a value-added package can help the consumer transport the product home easily and that can contribute to easy marketability of the product [13].

The consumption of sea and freshwater food including fish has gained popularity as more people are becoming concerned to maintain good health free from food related ailments, Malawi lacks behind in fish quality and value addition capacity due to low skill, limited resources and lack of awareness. Fish quality and value addition are of major concerns in Malawi as it is estimated that $40 \%$ of the annual catch is lost through post-harvest spoilage and insect infestation translating into an economic loss in terms of beach value of around MK8.4 billion annually, 
(NFAP, 2016) [4]. It is therefore, necessary to create awareness, build capacity and assess profitability on fish value addition through packaging of fish and fish products in Malawi.

\section{Materials and Methods}

The study was conducted in Linga Extension Planning Area in Nkhotakota district, central Malawi. A lot of households residing in Linga EPA rely almost exclusively on fisheries business activities as their livelihood.

\section{Sample collection}

69 kilograms of fresh E. sardella fish were purchased at a local market along Vinthenga beach along Lake Malawi in Nkhotakota district. The fish were dried in a solar tent dryer for 2 days. Out of the $69 \mathrm{~kg}, 34.5 \mathrm{~kg}$ were packaged in transparent plastic bags weighing $500 \mathrm{~g}$ each and the other half $(34.5 \mathrm{~kg})$ was not packaged and were sold at the same market in Nkhotakota district.

\section{Profitability Analysis}

Cost and return analysis were used to determine the cost and returns of small scale fish business of packaged and unpackaged E. sardella.

Profitability ratios; benefit cost ratio, return of investment were used to analyze the profitability and viability of value added E. sardella by packaging and not packaging.

\section{Benefit- cost ratio}

The cost benefit ratio was also calculated to determine the economic viability of E. sardella of value added $E$. sardella through packaging. The ratio was calculated in the absence of discounting as the costs and revenues were all within a time frame of less than a year. The following equation was used:

$$
\mathrm{BCR}=\mathrm{TR} / \mathrm{TC}
$$

Where BCR is the benefit-cost ratio, TR is total revenue and TC is the total cost

$$
\mathrm{BCR}=\mathrm{TR} / \mathrm{TC}
$$

Where;

$\mathrm{BCR}=$ Benefit cost ratio

$\mathrm{TR}=$ Total revenue

$\mathrm{TC}=$ Total cost

\section{Return on Investment (ROI)}

Return on investment was calculated as follows profit/total cost. This shows how much money is returned when every Mk1 is invested in the business.

Return on Investment (ROI) $=$ Profit $/$ Total cost

$$
\mathrm{TR}=\mathrm{TO} * \mathrm{USP}
$$

Where, TR is total revenue (Mk), TO is total output while USP is unit selling price

Total costs were also calculated by summing up both the variable and fixed costs. The following equation was used:

$$
\mathrm{TC}=\mathrm{VC}+\mathrm{FC}
$$

Where TC is total cost (MK), $\mathrm{VC}$ is variable cost (MK) and $\mathrm{FC}$ is fixed cost (MK)

Gross profit compares the fishers, and fish processors' total revenue and the variable costs that were incurred, as illustrated by the following equation:

$$
\mathrm{GM}=\mathrm{GR}-\mathrm{VOC}
$$

Where GM is gross margin (MK), GR is gross revenue (MK) and VOC is variable operating cost (MK).

The net profit was calculated to compare E. sardella sales through the different models as well as value added E. sardella through packaging. This is also referred to as the economic profit. It was calculated using the following equation:

$$
\mathrm{NP}=\mathrm{GR}-\mathrm{TC}
$$

Where NP is net profit (MK), GR is gross revenue (MK) and TC is total cost (MK).

\section{Statistical Analysis}

Data on profitability of value added E. sardella was analyzed using the Statistical Package for Social Scientists (SPSS,20.0). Analyses were carried out by calculating static indicators involving the total revenue which refers to the total amount of money the enterprise has accumulated by selling packaged E. sardella fish versus unpackaged E. sardella.

\section{Results and Discussion}

\section{Profitability Analysis of Value added E. sardella by Packaging}

Results of the present study (Table 1), show that packaging of Engrauricypris sardella increased the selling 
price of the fish from Mk4, 528.00 (5.5 USD) per $1.5 \mathrm{~kg}$ to Mk9, 800.00 (11.8 USD) per $1.5 \mathrm{~kg}$. The total sales of $34.5 \mathrm{~kg}$ of unpackaged E. sardella was generated gross profit of Mk104, 144.00 (125.5 USD) against Mk225, 400.00 (271.6 USD) from the sales of same quantity of packaged E. sardella with a net profit of Mk83, 694.24(100.84 USD) and Mk185, 050.00 (222.95 USD) respectively. The packaging of Engrauricypris sardella increased the aesthetic appeal of the fish and enhanced consumer preference to buy and were willing to pay extra cost. The profitability and viability of packaged E. sardella business was further verified by the level of ROI and BCR (Table 1).
The rates of return on investment for unpackaged and packaged E. sardella were 4.09 and 4.58 respectively. This means every Mk1.00 invested there was a return of Mk4.09 for unpackaged E. sardella and Mk4.58 for packaged E. sardella. The benefit cost ratio was 5.09 for unpackaged E. sardella and 5.58 for packaged E. sardella. In both cases it shows that the business was viable because the benefit cost ratio was above 1, however the profitability and viability was highly enhanced by packaging.

\begin{tabular}{|c|c|c|}
\hline Expenditure & Solar tent dried unpackaged E.sardella & Solar tent dried packaged E.sardella \\
\hline Procurement of fresh fish & $17,250.00$ & $17,250.00$ \\
\hline Basins & 900.00 & 900.00 \\
\hline Solar tent rentals & 500.00 & 500.00 \\
\hline Transport & $1,000.00$ & $1,000.00$ \\
\hline Packaging materials & - & $20,700.00$ \\
\hline Carrying baskets & 800.00 & - \\
\hline Total cost & $\mathbf{2 0 , 4 5 0 . 0 0}$ & $\mathbf{4 0 , 3 5 0 . 0 0}$ \\
\hline Benefits (Income) & $104,144.92$ & $225,400.00$ \\
\hline Revenue & $104,144.92$ & $225,400.00$ \\
\hline $\begin{array}{c}\text { Discounted benefits Interest } \\
\text { Payment }\end{array}$ & $24 \%$ & $24 \%$ \\
\hline Operation cost (Interest rate) & $24 \%$ & $24 \%$ \\
\hline Fixed cost (Interest rate) & $83,694.92$ & $185,050.00$ \\
\hline Gross returns & $83,694.24$ & $185,050.00$ \\
\hline Discounted benefits & 5.09 & 5.58 \\
\hline Cost benefit ratio & 4.09 & 4.58 \\
\hline ROI & & \\
\hline
\end{tabular}

Table 1: Cost benefit analysis of Engracyprius sardella.

The results of the present study on packaging mirrors prior research as reported by FAO [10], that producers who add value to their products fetch a larger share of the food dollar by producing what consumers demand instead of producing and supplying to markets only raw materials. Russel, et al., corroborates findings of the present study that one of the reasons for promoting value added products is to achieve higher profits and affirms that value addition can be further be enhanced by good packaging and labelling.

In the present study, the packaged and unpackaged Usipa (E. sardella) were sold at Nkhotakota central market as a sample to assess the profitability of the unpackaged and unpackaged fish. Packaging presents the products to be admirable, hygienic and free from pathogens. The packaged E. sardella looked attractive and safe since there were no flies as it was with unpackaged heaps of E. sardella which were almost covered by flies. The customers who looked smart and possibly sensitive to health issues avoided the unpackaged E. sardella. This gave a notion that targeting bigger markets where affluent people form integral part of buyers such as super markets would have generated more income to the fish processors. Packaging enhances aesthetic appeal and attracts the consumers, attributes that are very important for fish and fishery products [12]. In addition, valueaddition by packaging can help the consumer transport the product easily and that contribute to easy marketability of the product [13] and minimize losses due to scattering and deterioration. Therefore in conclusion, Packing of fish enhanced profit by improving consumer 
preference. Consumers were attracted to the packed fish because they were safe from pathogens and had good aesthetic appeal. As such, the study advocates for value addition fish and fish products through packaging at all levels to improve sanitation, economic viability of fisheries resources and health of consumers. Future research must target sales of packaged fish at super markets on high value fish species.

\section{Acknowledgement}

Authors would like to express their profound gratitude to CABBMAC for financial assistance.

\section{References}

1. Yoyola L, Dzanja J, Kakota T, Hara M (2013) Value Chain Analysis of Lake Malawi Fish: A Case Study of Oreochromis species (Chambo). Int J Business Soc Sci $4(2)$.

2. Carvalho N, Edwards-Jones G, Isidro E (2011) Defining scale in fisheries: Small versus large-scale fishing operations in the Azores. Fisheries Research 109(2): 360-369.

3. GoM (2011) Annual Economic Report. Draft report. Ministry of Development Planning and Cooperation. Lilongwe, Malawi.

4. NFAP (2016) National Fisheries and Aquaculture Policy. $2^{\text {nd }}($ Edn.), Ministry of Agriculture, Irrigation and Water Development; Lilongwe, Malawi.

5. GoM (2007) Overview of Fish and Fish Trade in East and South Africa Region: The Fisheries Sector and Its Importance in Malawi.
6. FAO (2005) Fishery country profile. Food and Agriculture Organization of the United Nations.

7. Russell A, Dobson T, Wilson J (2008) Fisheries management in Malawi: A patchwork of Traditional, modern, and post-modern regimes unfolds. In: Taylor WW, Schechter MG, and Leonard NE (Eds.). American Fisheries Society, pp: 53-98.

8. FAO (2012) Fisheries and Aquaculture Statistics. Food and Agricultural Organization of the United nations.

9. Kapute F, Singini W, Valeta J, Kamanga J (2015) Sustainable Environment and Enterprise Development for climate change adaptation in Fisheries (SEED-Fish) baseline report. Unpublished project baseline report. Lilongwe University of Agriculture and Natural Resources, Lilongwe, Malawi.

10. FAO (2011) Global food losses and food waste-extent, causes and prevention. Rome. United Nations; FAO.

11. Barry PJ, Ellinger PN, Baker CB, Hopkins JA (1995) Financial management in agriculture [M]. Interstate Publisher, Darville, Illinois.

12. De Silva D, Masahiro Y (2006) Regional preferences in the Japanese Seafood consumption: An empirical analysis of consumer purchasing behavior on domestic versus imported seafood. J Regional Fisheries Society Japan 46(2): 83-104.

13. Susan B (1988) Packaging: A key Element in Added value. Journal of Food Distribution Research 88: 6-11.

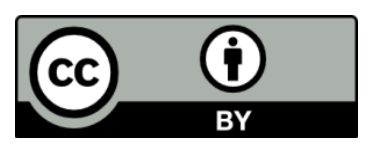

Mbamba D, et al. Profitability Analysis of Value Added Usipa (Engraulicypris Sardella) by

Packaging in Nkhotakota, Malawi. J Ecol \& Nat Resour 2018, 2(3): 000134. 